\title{
Moving Westward: The Azerbaijan DEEP Experience
}

\author{
Thomas Fedyszyn *
}

Azerbaijan confronts a unique set of challenges and opportunities as it conducts a foreign policy aimed at alienating none of its neighbors while also modernizing its society and armed forces. While never applying for NATO membership, Azerbaijan still desires all the resources NATO makes available to its aspirants and other members of the Partnership for Peace. Thus, she faces the dilemma of determining in which strategic direction she will eventually lean, while in the process not actually leaning too far.

On the one hand, this secular Muslim nation is an ideal candidate for modernizing its military by bringing it up to NATO standards. Located on the Caspian Sea, Azerbaijan prides itself on being able to conduct friendly foreign relations with its neighbors, while also projecting an image of regional strength and preparedness. Its capital, Baku, is obviously flush with oil revenues, as evidenced by its well-groomed public spaces, magnificent architectural showcases, and high-fashion stores matched in few other European capitals. Its youth walk the boulevards of Baku wearing Western styles and listening to European popular music. However, it also maintains its local culture and traditions, which have only fitfully welcomed Western ideas. Outside of its main cities, Azerbaijani society has eased somewhat reluctantly into the twenty-first century. Both Russia to its north and Iran to its south send subtle messages that Europeanization is neither a correct nor realistic model. Adding to this friction is the pressing reality that Azerbaijan continues to be embroiled in a "frozen conflict" with Armenia over the status of NagornoKarabakh. The push and pull of these forces makes this decision over determining a "strategic direction" difficult. This article contends that the creation and development of a defense education program aimed at assisting the Azerbaijani Armed Forces to develop along the lines of a Western (NATO) model is a powerful force in persuading Azerbaijan to look westward.

\section{Remodeling Defense Education}

The Azerbaijani Ministry of Defense decided to improve its system of professional military education in 2008 with the help of NATO, particularly when it was clear that all its neighbors in the Caucasus were arriving at the same conclusion. Through its Individual Partnership Action Plan (IPAP), Baku showed interest in a number of defense educational fields including NCO training, specialized officer's training, and an extensive overhaul of all senior officer military education conducted at the Military College of the

\footnotetext{
Dr. Thomas Fedyszyn is the NATO Academic co-lead for the Azerbaijan DEEP Program. He is Professor of National Security Affairs and Director of the Europe-Russia Studies Group at the U.S. Naval War College in Newport, Rhode Island, USA. A former naval officer, he has commanded a cruiser and destroyer while also serving as the U.S. Naval Attaché to Russia. He has published extensively on NATO, the Russian Navy and maritime strategy.
} 
Armed Forces (MCAF) in Baku. Thus began Azerbaijan's Defense Education Enhancement Program (DEEP) with NATO in 2009.

The first element of the program, non-commissioned officers' (NCO) training, was provided by representatives from Allied Command Transformation (ACT), Allied Command Operations (ACO), Lithuania and the United States. Several team visits resulted in the creation of plan for the development and implementation of a holistic upgrade of the role and position of the Azerbaijani NCO corps. The NATO team focused on building courses on NCO professional careers and NCO instructors.

Specialized Officer's Training, the second element of the program, began with a review of the courses offered at the Azerbaijani Education and Training Center by NATO representatives from the Czech Republic, Poland, Romania, and the United States. These courses are principally technical and tactical in nature, and are designed for a junior officer's professional military development. Both of the above elements are supported by the Partner Language Testing Center Europe (PLTCE) with the goal of building an independent Azerbaijani capacity for language training. Using language training structure assessments, NATO's Bureau for International Language Coordination (BILC) has been able to provide language training programs and tailored assistance with an eye toward building an independent Azerbaijani language training capacity. In addition, Azerbaijani students regularly attend courses in various NATO schools on a wide range of professional and technical topics. Their principal goal is to enable interoperability between the Azerbaijani Armed Forces and NATO in areas related to logistics and peace support operations.

\section{Senior Officer Professional Military Education}

The third - and by far the most significant - element of the NATO DEEP initiative is the effort to improve and modernize the courses of study available to senior military and governmental officials in Azerbaijan. Known in the United States as Joint Professional Military Education (JPME), this project began in late 2009 with consultations between NATO officials and the senior leadership of Azerbaijan's MCAF, their war college equivalent. Baku's principal desire was to enhance its curriculum in defense strategy and planning. NATO responded enthusiastically. The Alliance philosophy was consistently one of developing the defense education infrastructure in Azerbaijan, enabling them to ultimately wean themselves from dependence on NATO. Performing this task at the graduate level, however, is vastly more complex than the usual "train the trainers" motto for the development of NCOs and junior officers, because there is a qualitative difference between education and training

NATO's first step was to recruit a permanent team of war college professionals capable of analyzing all elements of the challenge and developing a strategy that tailored a curriculum specifically for Azerbaijan and also enabled local faculty to teach it. The NATO academic team was led initially by the U.S. National Defense University, and subsequently by a professor of national security affairs from the U.S. Naval War College. The team members included faculty from the Naval War College in Newport and the U.S. Army War College in Fort Leavenworth, in addition to the National Defense 
Universities of the Czech Republic and Poland. Their first challenge, in a nation on a war footing, was persuading the Azerbaijani military that developing an "operationalstrategic" perspective must work hand-in-hand with the operational and tactical exigencies of the day. The extant curriculum at MCAF (the intermediate level of JPME) was focused on pressing near-term tactical issues revolving around the Nagorno-Karabakh conflict with Armenia. Most of the students in this two-year course were majors who had just returned from battle. Their second challenge was to revamp a curriculum and teaching style based on a Soviet philosophy and pedagogy. Teachers and students alike knew only one way to learn, and most considered it pedagogically unsound. Finally, they had to develop a plan whereby the local faculty could sustain the new curriculum and teaching style long after the NATO DEEP team departed.

Consultations on the current state of the curriculum were very constructive, owing largely to the enthusiasm of the MCAF leadership and its faculty in the adoption of a more "Western" course of study. Not surprisingly, most NATO defense colleges follow the same strategic logic in the determination of force planning requirements (defense strategy and planning). The resulting curriculum also requires expertise in international relations, political science, and regional studies, augmented with an understanding of leadership, management, psychology, economics, and ethics. The Azerbaijani faculty included both military officers and civilians, with its civilian professors having sufficient credentials to manage the academic transformation. Considerable help from their NATO counterparts provided a useful catalyst. This developed into a series of visits by the NATO team that focused on demonstrations of teaching techniques in the classroom as well as substantive curricular discussions with professors.

NATO's first forays into the classroom provided evidence that the teaching styles in post-Soviet war colleges and those of the West were widely disparate. Newport's small, engaging seminars with steady student participation were contrasted with a classroom of students expecting a formal lecture on the topics of the day. The NATO team had little trouble convincing the MCAF leadership and faculty of the value of the Socratic method (students questioning one another and ultimately helping teach themselves) in the war college classroom, although both sides acknowledged the barriers posed by cultural, societal, and historical norms. The NATO teams, therefore, decided that every NATO visit would include not only faculty-to-faculty curricular consultations, but also NATO professors providing "lectures" that would gradually transform into seminar discussions instead of one-way communications.

\section{Shadow Faculty Initiative}

These in-country visits (normally three a year) were insufficient to jump-start all facets of this education transformation. Curricular development based solely on readings, teaching notes, and professional discussions provided by Western experts during these visits were not creating sufficient momentum to enable reform to happen quickly enough. Additionally, little of this material was tailored to Azerbaijan, and the local faculty needed to adapt it before it became usable in the MCAF classroom. Therefore, to energize this program, the NATO team proposed in late 2009 a "Shadow Faculty Initia- 
tive," whereby Azerbaijani faculty would spend a few weeks at Western war colleges virtually shadowing their counterpart faculty there. Not only would they get the entire immersion experience of how Western seminars operate, they would also witness the crafting of teaching notes, attend workshops in preparation for subsequent sessions, and develop a better understanding of the flexibility of Western teaching styles. For the last two academic years, two Azerbaijani professors have "shadowed" faculty in Newport for the better part of two weeks. They left not only with reams of academic material but also with a better personal understanding of how senior U.S. military professionals develop their strategic understanding of national security affairs. Their most recent visit allowed them to also witness classrooms covering leadership, military history, civilmilitary relations, and ethics, in addition to the syllabus staples of defense strategy and planning. The highlight of the second visit was their presentation of a professional lecture to the Newport faculty on Azerbaijan's national security challenges.

Following this experience in the United States, MCAF faculty had similar, albeit shorter, visits to the defense universities of Poland and the Czech Republic. This is notable because Azerbaijan has numerous similarities with these countries, as all were European nations with mid-sized militaries formerly affiliated with (or incorporated into) the Soviet Union. Further, Azerbaijan wanted to emulate other war colleges in their ability to award advanced degrees. Both Poland and the Czech Republic used the European system based on the Bologna Model, and the European NATO team members were convinced that Azerbaijan could follow along these lines. Thus, much of the "shadowing" in Brno (Czech Republic) and Warsaw (Poland) related to Azerbaijan developing an appreciation of the construction of the Bologna system, which could be transplanted into Azerbaijan. Thereby, Azerbaijan's plans to grant graduate degrees in military science has taken large steps forward, which will culminate in MCAF awarding its first Masters degrees in 2014 to the graduates of its two-year intermediate course. Romania, another new NATO member, has also volunteered to work with Azerbaijan on related topics of professional military education.

A second initiative proposed by the NATO team was the adoption of an end-of-year final exercise, enabling the students to integrate their classroom efforts by developing a national security strategy for Azerbaijan and corresponding operational concepts, capability requirements and, ultimately, defense budgets. Again, this effort required significant effort on the part of the MCAF faculty, since the mid-level students are preoccupied with tactical-operational (not strategic) matters, and they consider the determination of national strategy to be completely beyond their status and seniority. Nonetheless, the MCAF faculty intends to add such an exercise to this year's intermediate-level course curriculum.

In three years, Azerbaijan's course of study for its future military leadership (today's majors) was given a revolutionary upgrade. This multinational team effort has resulted in significantly revamping both the curriculum as well as the teaching styles for the middle-grade officers in the two-year course for intermediate-level JPME. 


\section{Expanding Course Offerings}

The NATO team was pleasantly surprised to discover that majors were not the only senior students enrolled at the MCAF. Indeed, there is also a senior officer interagency defense management course, attended by approximately twenty students, a minority of them from the Ministry of Defense. This course was inaugurated in 1999, and is taught only for half-days over five months because the students are expected to tend to their day jobs during the second half of the day. This course presented a qualitatively different challenge to the DEEP team because the students were already seasoned practitioners in the world of defense management and well adapted to the interchanges of seminar-style learning. The Turkish Ministry of Defense was largely responsible for earlier assisting Azerbaijan in the development of this course.

NATO assistance in the improvement of this course was centered on the application of "whole of government" approaches to the security challenges facing Azerbaijan. Not only must local leaders take into account the nation's "frozen conflict" over NagornoKarabakh, they must also consider issues of energy security, pollution, alliances, and domestic terrorist movements. While few of the students in this course had previously received education along the Western model, they took extremely well to the participatory seminar style encouraged by the NATO team. The NATO effort was concentrated on techniques for interagency planning and a final exercise, similar to that added to the JPME Intermediate offering, was also added to this course. Somewhat serendipitously, a number of the Azerbaijani students in this class were familiar with the efforts of a team of Naval War College war gamers who had helped them develop contingency planning for the safeguarding of the nation's petroleum infrastructure in the Caspian Sea in 200809.

One final opportunity (perhaps the greatest of all) was provided to the NATO team when the commandant of the MCAF announced in early 2012 that Azerbaijan had resolved to create a senior officer ten-month course for those colonels selected to be generals and other upwardly-mobile senior officers. In November 2012, Azerbaijan determined that the five-month course described above would be folded into this new course as the national security affairs portion of the course, and an additional five-month segment on "strategic-operational" issues would be added. This course is scheduled to convene for the first time in the fall of 2013, to include fifteen to twenty students. The civilian students would take only the national security portion (the first five months). The goal was to create a strategic-level course enabling its graduates to both serve as strategic battlefield commanders as well as masters of defense strategy and planning for service in the defense bureaucracy. A recently retired Azerbaijani general has been put in charge of its curriculum development, and the U.S. Naval War College is providing recommendations and guidance in its development. Not only will it be a course heavy in grand strategy and national security affairs, but joint military operations will also be a central part of its core curriculum. The faculty at MCAF is working toward getting academic accreditation for a Master's degree in the equivalent of national security affairs for all ten-month course graduates. 


\section{Challenges Ahead}

While the amount of success that the NATO DEEP effort in Azerbaijan has had in such a short time (three years) cannot be ignored, other stumbling blocks remain. First, the primary challenge to the creation of this new curriculum is that a number of topics and sessions developed for the intermediate course must now be either moved to or upgraded for the senior course. Further, with each new course developed by the MCAF, there is a need to recruit and train new faculty. For its part, the U.S. Naval War College has agreed to use the next Shadow Faculty event to support the development of the senior officers' course and to ensure that its Azerbaijani creators spend sufficient time with the Joint Military Operations Department faculty. Following its creation, NATO DEEP and the MCAF will be required to make a top-down audit of its courses of study, ensuring that their seamless academic flow is not interrupted with unnecessary duplication. The intent will be a steady and logical development of a joint professional military education curriculum, from commissioning through flag and general rank.

Second, NATO DEEP projects at all levels (NCO, specialized officer, and postgraduate) would be enhanced by a superior facility in English in the Azerbaijani military. While NATO continues to offer language training support through BILC, and a number of nations offer this support bilaterally, it is recommended that Azerbaijan make more extensive use of this opportunity. Improving overall English facility would be especially helpful in the development of a more professional corps of NCOs. "Training the trainers" has unique applicability in courses for non-commissioned officers, and the gap between officers and enlisted men in the Azerbaijani Armed Forces should be addressed.

Third, Azerbaijan's near-total obsession with Nagorno-Karabakh and its enmity towards Armenia make it difficult to focus on strategic matters beyond this issue. Whenever a NATO instructor drops his guard for the slightest moment, every topic in the classroom seems to finds its way back to Nagorno-Karabakh. A widening of the strategic lens beyond this stubborn conflict is necessary if true reforms in defense education are to take place in Azerbaijan.

\section{Prospects for the Future}

Azerbaijan shows every sign of prosperity and vitality. Its recent hosting of the 2012 Eurovision competition was a source of pride for its citizens and provided eye-opening experiences for first-time European tourists. While Baku makes every effort not to alienate any of its neighbors, there is increasing talk of Azerbaijan becoming a Western bulwark in the Caucasus - in short, "everything that Iran is not." While this is a journey whose difficulty cannot be overestimated, the Azerbaijani Military Academy's increasing connection with Western military education and thought processes inevitably draws this very significant element of its society closer to the NATO mindset. Azerbaijan's NATO DEEP experience, while still young and growing, is a short-term success with

1 Joby Warrick, “Tiny Azerbaijan Unleashes Pop-Power Against Iran's Mullahs," Washington Post (14 October 2012). 
FALL 2012

opportunities to make increased and meaningful contributions to this development. As a result, Azerbaijan is slowly and subtly beginning to turn its gaze westward. 
THE QUARTERLY JOURNAL

\section{Bibliography}

Warrick, Joby. "Tiny Azerbaijan Unleashes Pop-Power Against Iran's Mullahs." Washington Post (2012). 